\title{
Achillodynie u rekreačních běžců
}

\section{Achillodynia in recreational runners}

\author{
Soňa Palovičová, Jana Řezaninová
}

Fakulta sportovních studii Masarykovy univerzity, Brno

\begin{abstract}
Abstrakt
Běhání se v dnešní době stalo novodobým trendem a jednou z nejoblíbenějších volnočasových aktivit. S popularitou běhu souvisí častý výskyt akutní nebo chronické bolesti Achillovy šlachy v ordinaci fyzioterapeutů i lékařu. Přičina achillodynií u běžců není jednoznačně objasněna, proto považujeme za důležité upozornit na rizikové faktory a význam prevence.
\end{abstract}

Klíčová slova: běh, achillodynie, terapie, prevence

\begin{abstract}
Running has become a modern trend and one of the most popular leisure activities. The popularity of running however results in an increased occurrence of cases of acute or chronic pain of the Achilles tendon in offices of doctors and physiotherapists. The cause of achillodynia in runners has not been conclusively established, hence it is important to warn about the risk factors and promote the importance of prevention.
\end{abstract}

Key words: running, achillodynia, therapy, prevention

\section{ÚVOD}

Běžecký boom začal počátkem 70. let 20. století a počet rekreačních běžců každým rokem postupně stoupá (Galloway, 2007; Tvrzník \& Gerich, 2014). S vývojem moderních technologií, aplikací pro různé aktivity a sociálních sítí se každý touží prezentovat co nejvyšším počtem naběhaných kilometrů a vysokým průměrným tempem v tréninku či umístěním v běžeckých závodech. Častým cílem je uběhnout co nejdelší vzdálenost co největší rychlostí, bez prožitku z pohybu, s cílem co nejlepšího umístění. Pohybový aparát běžce často není na takové zatížení připraven. $Z$ pohledu prevence bolesti a zranění pohybového aparátu je kvalita běžeckého stereotypu důležitější než kvantita naběhaných kilometrů.

Až $1 / 4$ běžců udává v průběhu sezony problémy v oblasti nohy a kotníku. Běh se po baletu řadí na druhé místo žebříčku četnosti poranění hlezna a nohy (Sobhani, Dekker, Postema, \& Dijkstra, 2012). Mnoho běžců se domnívá, že zranění ke sportu jednoduše patří. S tímto názorem se však neztotožňujeme. Dle Dannyho a Katherin Dreyer (2013) poranění pohybového aparátu běžců nezpůsobuje samotný běh, ale především jeho stereotyp.

\section{ANATOMICKÉ SOUVISLOSTI}

Achillova šlacha (AŠ) je nejdelší a nejsilnější šlacha v lidském těle. Ze všech šlach je nejvíce zatěžována a nejčastěji podléhá ruptuře. Dle Sobhani et al. (2012) je nejčastěji zraněnou šlachou u běžců a fotbalistů. Ristolainen et al. (2010) ve své práci uvádí, že achillodyniemi trpí více než 
50 \% běžců. Dle Kujala, Sarna a Kaprio (2005) achillodyniemi trpí alespoň jednou za život až $52 \%$ běžců na střední a dlouhé tratě a $32 \%$ běžců na krátké tratě. Roční incidence bývá přibližně 5,9\%. AŠ si během sledovaného nizozemského závodu Amgen Singelloop Breda poranilo 11,4\% běžců (Poppel, Scholten, Peeters, Middelkoop \& Verhagen, 2013). Při běhu musí šlacha odolávat síle až 12,5krát větší než je hmotnost lidského těla (Doral et al., 2010).

Tab. 1: Incidence zranění běžců (Zdroj: Madden, Putukian, McCarty \& Young, 2013)

\begin{tabular}{|l|c|}
\hline Zranění & Incidence (\%) \\
\hline Tibiální syndrom (zánět okostice) & $13,6-20,0$ \\
\hline Tendopatie Achillovy šlachy (achillodynie) & $9,1-10,9$ \\
\hline Patelofemorální syndrom & $5,5-22,7$ \\
\hline Plantární fascitida & $4,5-10,0$ \\
\hline Distorze hlezna & $10,9-15,0$ \\
\hline Iliotibiální syndrom & $1,8-9,1$ \\
\hline Poranění hamstringů & 10,9 \\
\hline Únavová zlomenina tibie & 9,1 \\
\hline
\end{tabular}

AŠ začíná na zadní straně lýtka, přibližně v jeho polovině, jako úponová šlacha musculus gastrocnemius a postupně distálně nabírá svalová vlákna $\mathrm{z}$ musculus soleus. Průměrná délka šlachy je u dospělého jedince přibližně $18,2 \mathrm{~cm}$. Její šiřrka je na začátku v průměru $3,4 \mathrm{~cm}$. Distálním směrem se zužuje, její nejužší místo se nachází asi ve $4 / 5$ šlachy, kde dosahuje šiřky přibližně $1,8 \mathrm{~cm}$. Od tohoto místa se šlacha opět rozšiřuje až na $3,4 \mathrm{~cm}$. Zastoupení m. soleus a m. gastrocnemius v AŠ bývá dost variabilní a vzhledem na měnící se orientaci vláken značně obtížně určitelné. Podle pitevních záznamů je zastoupení m. gastrocnemius u nadpoloviční většiny víc než 50\%, následuje rovnoměrné zastoupení obou svalů ve šlaše, a jen u malého počtu jedinců najdeme výraznější podíl m. soleus. Tvar úponu byl popisován jako trojúhelníkový, dnes se však považuje spiš za poloměsíčitý s více prominentním mediálním a menším laterálním rozšířením. Jedná se o velice specifické osteotendinózní spojení mezi šlachou a kostí, které netvoří jen vazivo, ale i okolní struktury. Proto dostala AŠ označení „úponový orgán“ („the enthesis organ“), který by měl být schopen rozptýlit tlak působící na šlachu. Je formován spojením mezi AŠ a calcaneem, sezamoidní fibrózní chrupavkou blízko úponu šlachy, vrstvou fibrózní chrupavky pokrývající periost hrbolu patní kosti a Kagerovým tukovým polštářem. Distálně od šlachy jsou dvě burzy. Bursa retrocalcanearis leží mezi AŠ a zadní plochou calcanea a umožňuje volný pohyb mezi šlachou a kostí. Její přední vrstvu tvoří vazivová chrupavka a tenká zadní vrstva splývá se šlachou. Povrchní bursa calcanea subcutanea se nachází mezi šlachou a kůží. Cévní zásobení šlachy je zabezpečeno přes arteria tibialis posterior a arteria peronea (fibularis). Nejméně vaskularizovaná je střední část šlachy. Inervaci zajištuje především nervus suralis s podporou nervus tibialis. Aferentní receptory jsou lokalizovány hlavně v okolí osteotendinózního spojení a zahrnují všechny typy receptorů: Ruffiniho, Vater-Pacciniho i Golgiho šlachová tělíska a volná nervové zakončení (Doral et al., 2010).

Z pohledu Myerse (2013) je AŠ funkční součást zadní povrchové myofasciální linie těla. Začíná aponeurózou krátkých flexorů prstů, pokračuje jako plantární fascie, která je uprostřed chodidla zesílená a tvoří plantární aponeurózu. Dle Myerse (2013) se plantární fascie upíná na anterio-inferiorní část calcanea, konkrétně na periost, a pokračuje jako povrchní část AŠ. Jedná se o první myofasciální spojení zadní povrchní linie: plantární fascie - patní kost - AŠ. Dlouhodobě zvýšené napětí v této myofasciální linii (nejčastěji při anteverzním postavení pánve) může způsobit decentraci patní kosti směrem do subtalárního kloubu. Linie pokračuje prostřednictvím m. ga- 
strocnemius, který se přes kondyly femuru napojuje na $\mathrm{m}$. semitendinosus a $\mathrm{m}$. semimembranosus na mediální straně stehna a m. biceps femoris na laterální straně stehna. Celá zadní povrchová linie je znázorněna na obrázku 1.
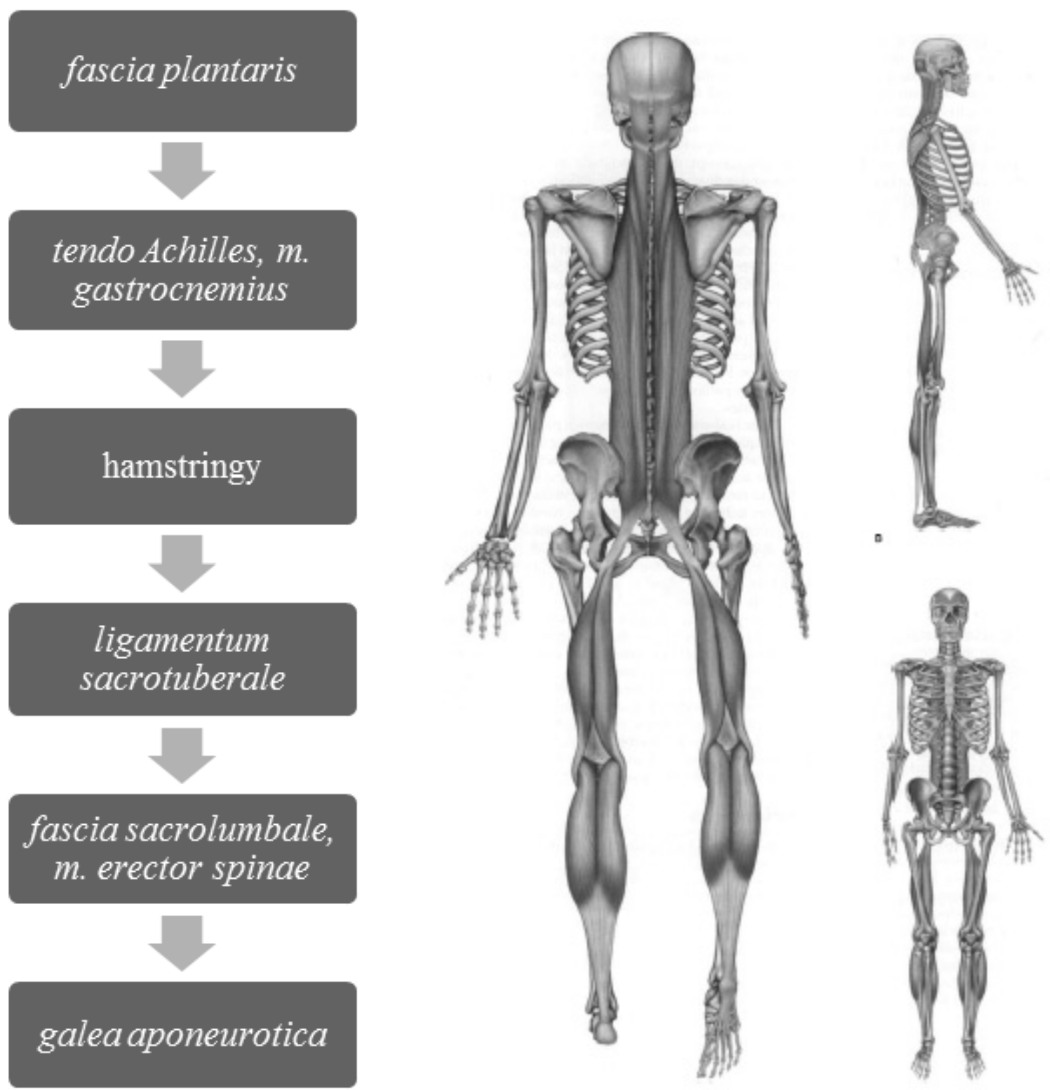

Obr. 1 Zadní povrchová linie (Zdroj: Myers, 2013)

\section{RIZIKOVÉ FAKTORY}

Rizikové faktory přetížení a poranění AŠ př̀ běhu lze rozdělit na vnitřní (aktuální schopnosti a výkonnost běžce, stereotyp běhu, antropometrické parametry, vaskularizace šlachy, biologické a genetické faktory, předchozí zranění) a zevní (běžecký povrch, obuv a tréninkové zatížení). Mnoho běžeckých zranění souvisí s technikou běhu. Nejčastěji je udávána: výrazná vertikální reakční síla od podložky, nadměrná pronace nohy, nadměrná addukce v kyčelním kloubu, pokles pánve a valgózní postavení kolen během stojné fáze. Nejrizikovější je právě kombinace zmíněných odchylek od centrovaného postavení v kloubech. Významnými faktory jsou také předchozí zranění a nevhodně zvolený tréninkový plán a objem (Kozinc \& Sarabon, 2017). Theisen, Malisoux, Gette, Nührenbörger a Urhausen (2016) ve své studii uvádí za hlavní prríčinu běžeckých zranění výběr obuvi, došlap a samotnou biomechaniku pohybu při běhu. 


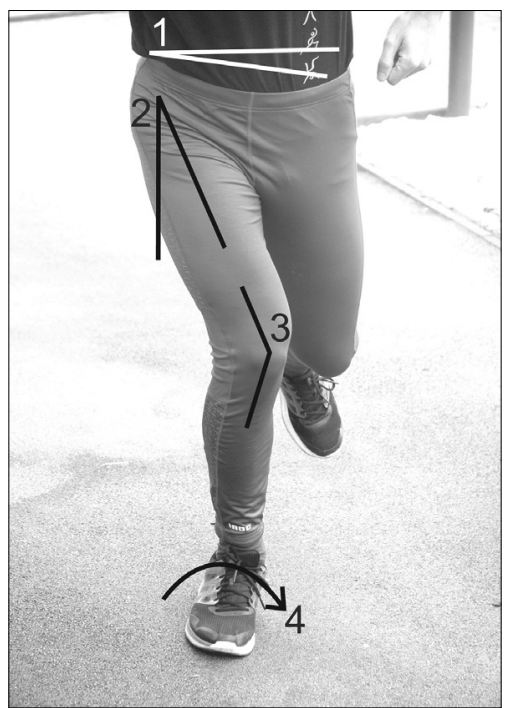

Obr. 2 Nejčastější rizikové faktory běžeckých zranění z pohledu kinematiky

(Zdroj: Kozinc \& Sarabon, 2017)

Při kontaktu běžce se zemí na něj působí reakční síla podložky, která má vertikální i horizontální složku. Tato síla závisí na hmotnosti běžce, rychlosti běhu, typu došlapu, tlumivých účincích obuvi, tvrdosti povrchu a jiných méně významných aspektech. Hned při dopadu můžeme pozorovat rozdíl pákových sil pohybu. Při došlapu přes patu se noha nachází v dorzální flexi a osa otáčení pohybu je v okolí zevního kotníku nad místem dopadu, zatímco noha dopadající na přední část chodidla je v plantární flexi a osu otáčení má v okolí hlavičky pátého metatarzu. Podle Tvrzníka a Gericha (2014) bude tedy na AŠ působit při běhu přes paty mnohonásobně menší síla než při běhu přes špičky. Avšak vertikální reakční síla působící na nohu v iniciální fázi prvních 50 ms bude víc než trojnásobně vyšší. Tato síla následně přechází přes dolní končetinu ke kyčelnímu kloubu a může se řetězit kontralaterálním směrem ještě výš a způsobovat zranění a přetěžování na jiných částech těla. Při opačném stylu je tato nárazová síla tlumena aktivní kontrakcí lýtkových svalů.

Průběh vertikální síly vztažené na hmotnost běžce se v následujících fázích cyklu u různých typů došlapu př́liš nemění a dosahuje maxima ve výšce asi 2,5násobku hmotnosti běžce těsně před polovinou stojné fáze (Knapik, Pope, Orr \& Grier, 2015). Došlap ovlivňuje také pokles klenby a centrální části nohy. Při běhu přes přední část chodidla je tento pokles výraznější, a tím je i energie uložená ve vazivech s nároky na jejich pružnost a funkčnost vyšší (Lieberman et al., 2010). Rychlost také určitým způsobem ovlivňuje došlap běžce. Při rychlosti menší než $5 \mathrm{~m} / \mathrm{s}$ $(18 \mathrm{~km} / \mathrm{h})$ je procentuální zastoupení běžců přes zadní, střední a přední část chodidla 70:24:6. Při vyšší rychlosti dochází $\mathrm{k}$ posunu ve prospěch běžců přes střední část chodidla, a to v poměru 47:47:6. Je však nutno poznamenat, že rychlost $18 \mathrm{~km} / \mathrm{h}$ je pro mnoho běžných rekreačních běžců nedosažitelná (Forrester \& Townend, 2015).

Dnešní moderní běžci mají díky tlumeným podpatkům z elastických materiálů tendenci došlapovat s aktivní dorzální flexí na patu, protože se to jeví jednodušší a komfortnější. Došlapem na patu ale noha ztrácí senzorickou zpětnou vazbu, která bosým běžcům pomáhá modulací kroku měnit dopad. Běžci se tak dostávají k tvrdému dupání při každém kroku. Tuhá podrážka bot se zahnutou špičkou kromě toho zjednodušuje práci měkkých struktur chodidla (plantární aponeuróza, vazy, šlachy, svaly) ve stojné a odrazové fázi, které následně ztrácí svou funkci a dochází k oploštění nožní klenby. Nefunkční klenba mění mechaniku celého chodidla a způsobuje sekundární změny v kotníku, kolenním i kyčelním kloubu, což může způsobit následná zranění 
(Lieberman, 2016). V opačném případě po příchodu „,barefoot boomu“ si běžci obouvají minimalistickou běžeckou obuv a zkouší v ní běhat svým tradičním běžeckým stylem. Neuvědomují si, že jejich pohybový aparát na takovou radikální změnu není ihned připravený a že je důležité začít postupně. Stává se, že se běžci v minimalistické obuvi hned aktivně snaží o došlap přes špičku. Na zem dopadají už s aktivní plantární flexí (koncentrickou aktivitou lýtkových svalů), která vzápětí musí plnit tlumicí funkci (excentrickou aktivitu), v jednom okamžiku tedy od lýtkových svalů vyžaduji koncentrickou i excentrickou kontrakci, což je značně zatěžuje a sekundárně může způsobovat reflexní změny.

Bylo publikováno mnoho studií, které posuzovaly vliv obuvi na výskyt běžeckých zranění. Ryan, Elashi, Newsham-West a Taunton (2013) porovnávali vliv klasické obuvi s neutrální podrážkou, částečně minimalistické a úplně minimalistické obuvi na úrazovost trénovaných účastníků, kteří se účastnili tréninkové př́pravy na závod na $10 \mathrm{~km}$ pod kontrolou. Během 12 týdnů postupně navyšovali dobu tréninku v jim určených botách z $19 \%$ v prvním na $58 \%$ v posledním týdnu. Zajímavým zjištěním bylo, že nejvyšší míra úrazovosti se vyskytla u běžců v částečně minimalistické obuvi (38 \%), pak následovala úplně minimalistická obuv (20\%) a nejmín úrazů postihlo běžce v klasické moderní obuvi (13\%). Co se týče bolestivosti, běžci nosící zcela minimalistickou obuv uvedli pomocí vizuální analogové škály (VAS) významné zvýšení bolesti lýtkových svalů a holení v porovnání s ostatními skupinami. Ridge et al., (2013) zkoumal vliv změny obuvi na kostní denzitu a riziko únavových fraktur pomoci magnetické rezonance. Už po 10 týdnech zjistili, že kostní změny indikující únavové zlomeniny byly téměř 9 krát vyšší než u klasických běžeckých bot. Doba přechodu u obou studií byla však krátká a nejsou známé výsledky dlouhodobější intervence. Grier et al. (2016), zabývající se vojáky americké armády, naopak nenašli žádný rozdíl v míře rizika zranění mezi klasickou a minimalistickou obuví. V této studii však nebylo jasné, jak dlouhou dobu běžci daný typ obuvi využívali.

Samotná změna obuvi z klasické $\mathrm{k}$ minimalistické tedy může být u běžců přičinou výskytu zranění. Je proto důležité se touto problematikou v době popularity běhu naboso (barefoot) zabývat (Fuller, Thewlis, Tsiros, Brown, \& Buckley, 2015). Při rozhodování o přechodu k minimalistické obuvi nebo bosému běhání by měli být běžci velice obezřetní, a když už se pro něj rozhodnou, je vhodné ihned nezahodit běžecké boty, vnímat své tělo a $\mathrm{k}$ bosému běhání přecházet postupně.

Přes všechny známé rizikové faktory a existující odborné studie zabývající se problematikou achillodynií u běžců zůstává etiologie nejasná. Jako hlavní příčina se zatím jeví nadměrné zatížení šlachy, která reaguje na opakované přetížení nad jejich fyziologickým prahem zánětem a degenerací šlachy (Kader, Saxena, Movin \& Maffulli, 2002; Ott et al., 2015). Dlouhodobé přetěžování lýtkových svalů může způsobit vznik bolestivých, aktivních trigger points $\mathrm{v} \mathrm{m}$. soleus a $\mathrm{m}$. gastrocnemius, jejich reflexní zkrácení, a tím zvýšený tah na šlachu s následnou tendinitidou šlachy. Běžci si v těchto př́ípadech stěžují na difuzní bolest AŠ v prvních minutách běhu, která se zhoršuje pohybem. Bolest bývá nejvýraznější $2-6 \mathrm{~cm}$ proximálně od úponu šlachy na calcaneus, ale může se difuzně šírit podél celé šlachy. Když je tendinitida závažná, lze zaznamenat otok, krepitace a uzlíky ve šlaše (Maffulli, Sharma \& Luscombe, 2004). Bolesti způsobené reflexními změnami (trigger points) v m. gastrocnemius mohou klinicky imitovat projevy tendinitidy Achillovy šlachy a retrocalcaneární bursitidy (Simons \& Travell, 1999).

\section{DIAGNOSTIKA A TERAPIE}

Klíčovou roli v diagnostice achillodynie má pečlivě odebraná anamnéza, kompletní kineziologický rozbor běžce a lokální vyšetření oblasti AŠ ideálně s využitím zobrazovacích (ultrasonografie, MRI) a př́istrojových metod (podoskop, dynamická platografie, izokinetická dynamometrie, 3D kinematická analýza došlapu a techniky běhu, popř́padě natočení běžce při běhu na kameru). 
Ke klinickému zhodnocení tendopatie Achillovy šlachy lze v praxi využít VISA-A (Victorian Institute of Sport Assessment-Achilles Questionnaire). Jedná se o jednoduchý asi pětiminutový dotazník, který posuzuje příznaky tendopatie a jejich vliv na sportovní a běžnou aktivitu. Dotazník obsahuje 8 otázek, které zahrnují 3 oblasti: bolest, funkci a aktivitu. V dotazníku lze dosáhnout maxima 100 bodů. Tato hodnota odpovídá asymptomatickému jedinci. Nižší počet bodů znamená více symptomů a větší limitaci ve sportovní aktivitě. O tendopatii AŠ lze uvažovat, když dotazovaný získá méně než 70 bodů. Při zisku více než 90 bodů můžeme naopak uvažovat o úplném uzdravení z tendopatie (Robinson et al., 2001).

Jak již bylo uvedeno, při diagnostice achillodynií lze využít zobrazovacích metod. Neinvazivní a relativně nenákladnou zobrazovací metodu bez vedlejších účinků v klinické praxi představuje ultrasonografie. Je využivána tradičně lékaři, využití fyzioterapeuty je u nás stále na počátku. Fyzioterapeuti můžou využít ultrasonografii (echografii) díky svým znalostem klinické a aplikované anatomie. Vyšetřením AŠ lze získat cenné informace o integritě šlachy a následně o průběhu hojení, na základě kterých je možné zvolit správnou terapii. V př́padě tendopatie vyšetření informuje o výskytu a rozsahu zánětlivých a degenerativních změn ve šlaše a jejím okolí (diagnostika retrokalkaneární burzitidy, patní ostruhy, tendinitidy s neovaskularizací). Ćástečné porušení kontinuity šlachy je známkou parciální ruptury. Typické místo kompletní ruptury je asi $3-4 \mathrm{~cm}$ od úponu na kalkaneus (Hrazdira \& Veselý, 1992).

V akutní i chronické fázi lze doporučit jako metodu první volby konzervativní terapii. V terapii je primární nalezení vyvolávající př́iciny a zmírnění symptomů. Snížení intenzity, trvání a frekvence aktivit, které způsobují bolest, úprava běžecké techniky, změna obuvi, dostatečná kompenzace, regenerace a individuální fyzioterapeutická intervence (měkké techniky k odstranění reflexních změn ve svalech, fyzikální terapie, kinezioterapie s využitím konceptů a metodik na neurofyziologickém podkladě, strečink zadní myofasciální povrchové linie, kineziotaping). Vzhledem k tomu, že reparace a přestavba kolagenních vláken jsou stimulovány zatížením šlachy, úplný klidový režim není doporučován. Při práci se sportovcem je neoddělitelnou součástí terapie i její implementace do konkrétního sportu. Snažíme se o pohybový stereotyp s centrovaným postavením kloubů, optimální kvalitní aktivací hlubokého stabilizačního systému, napřímení páteře a ideu samotného pohybu. Běžce učíme například stabilizovaný nákrok, náklon trupu, rotace trupu apod. Účast fyzioterapeuta přímo na tréninku je také velice důležitá. Dohliží na provedení atletických cviků a styl běhu a koriguje případné nedostatky. Cvičení pod dohledem fyzioterapeuta nebo domácí kompenzační cvičení by mělo být součástí přípravy každého výkonnostního sportovce i po odeznění zranění, aby se předešlo dalším případným potížím.

Studie autorů Li a Hua (2016) doporučuje v terapii achillodynií využít excentrické posilování lýtkových svalů, zejména když je postižena střední část šlachy (neúponová tendopatie AŠ). Při správném provádění se zvyšuje aktivita fibroblastů, zrychluje se tvorba kolagenních vláken a zvětšuje jejich tlouštka, následkem je větší síla, pevnost a hypertrofie šlachy (LaStayo et al., 2003). Excentrický trénink snižuje neovaskularizace, což eliminuje bolest a negativní příznaky tendopatie (Li \& Hua, 2016). Stasinopoulos a Manias (2013) ve své studii vyhodnotili jako nejefektivnější 12týdenní program dle Alfredsona kombinovaný se statickým strečinkem dle Stanishe. Program zahrnuje 3 série s 15 opakováními excentrického cvičení dvakrát denně s 2minutovou pauzou mezi sériemi. Běžec stojí na kraji schodu s podepřenými předními částmi chodidla a volnými patami. Nemocnou patu následně spouští dolů, čímž excentricky posiluje lýtkové svaly, a zdravou nohou se následně koncentricky vrací zpátky. Cvičení je vykonáváno při extendovaných i mírně flektovaných kolenních kloubech pro lepší aktivaci m. soleus. Statický strečink lýtkových svalů dle Stanishe je praktikován před a po zátěži, a to 3 krát po dobu minimálně 30 sekund na každý sval (m. gastrocnemius při extendovaném kolenním kloubu, m. soleus při flektovaném kolenním kloubu) s pauzou 1 minutu. Tato kombinace excentrického cvičení se statickým strečinkem dle 
výsledků studie zmírnila bolest, zlepšila funkci s redukcí patologií AŠ. Výhodou cvičení je, že ho edukovaný běžec může praktikovat sám.

I přes veškerou snahu fyzioterapeutů, lékařủ i samotných běžců nebývá konzervativní terapie vždy úspěšná. U 24-45,5 \% pacientů musí být zvažováno operativní řešení (Maffulli et al., 2004). Operační řešení je vhodné indikovat nejdřive po 4 měsících neúspěšné konzervativní terapie u chronických potíži (Li \& Hua, 2016).

\section{ZÁVĚR}

Článek podává aktuální přehled poznatků a doporučení pro prevenci výskytu achillodynií u rekreačních běžců. Přes všechny známé rizikové faktory a existující odborné studie zabývající se problematikou achillodynií u běžců zůstává jednoznačná etiologie stále nejasná. Za hlavní příčinu je považováno nadměrné zatížení šlachy při opakované zátěži během intenzivního tréninku, mikrotraumatizace šlachy a reflexní změny lýtkových svalů. Zásadní prevencí achyllodynií je vytvoření kvalitního individuálního běžeckého tréninku, regeneračního plánu a terapie nalezených dysbalancí.

\section{Reference}

1. Doral, M. N., Alam, M., Bozkurt, M., Turhan, E., Atay, O. A., Dönmez, G. \& Maffulli, N. (2010). Functional anatomy of the Achilles tendon. Knee Surgery, Sports Traumatology, Arthroscopy, 18(5), 638-643. https://doi.org/10.1007/s00167-0101083-7

2. Dreyer, D. \& Dreyer, K. (2013). ChiRunning: revoluční prístup k běhání bez námahy a zranění. Praha: Mladá Fronta.

3. Forrester, S. E. \& Townend, J. (2015). The effect of running velocity on footstrike angle - a curve-clustering approach. Gait \& Posture, 41(1), 26-32. https://doi.org/10.1016/j.gaitpost.2014.08.004

4. Fuller, J. T., Thewlis, D., Tsiros, M. D., Brown, N. A. T., \& Buckley, J. D. (2015). The long-term effect of minimalist shoes on running performance and injury: design of a randomised controlled trial. BMJ Open, 5(8), e008307. https://doi. org/10.1136/bmjopen-2015-008307

5. Galloway, J. (2007). Gallowayova kniha o běhání. Praha: Talpress.

6. Grier, T., Canham-Chervak, M., Bushman, T., Anderson, M., North, W. \& Jones, B. H. (2016). Minimalist Running Shoes and Injury Risk Among United States Army Soldiers. The American Journal of Sports Medicine, 44(6), 1439-1446. https:// doi.org/10.1177/0363546516630926

7. Hrazdira, L. \& Veselý, T. (1992). Praktická ultrasonografie v traumatologii a ortopedii dospělých. Brno: BOLIT - Bpress.

8. Kader, D., Saxena, A., Movin, T. \& Maffulli, N. (2002). Achilles tendinopathy: some aspects of basic science and clinical management. British Journal of Sports Medicine, 36(4), 239-249. https://doi.org/10.1136/bjsm.36.4.239

9. Knapik, J. J., Pope, R., Orr, R. \& Grier, T. (2015). Injuries and Footwear (Part 1): Athletic Shoe History and Injuries in Relation to Foot Arch Height and Training in Boots. Journal of Special Operations Medicine: A Peer Reviewed Journal for SOF Medical Professionals, 15(4), 102-108.

10. Kozinc, Ž. \& Sarabon, N. (2017). Common Running Overuse Injuries and Prevention. Montenegrin Journal of Sports Science and Medicine, 6(2), 67-74. https://doi.org/10.26773/mjssm.2017.09.009

11. Kujala, U. M., Sarna, S. \& Kaprio, J. (2005). Cumulative incidence of achilles tendon rupture and tendinopathy in male former elite athletes. Clinical Journal of Sport Medicine: Official Journal of the Canadian Academy of Sport Medicine, 15(3), 133-135. https://doi.org/10.1097/01.jsm.0000165347.55638.23

12. LaStayo, P. C., Woolf, J. M., Lewek, M. D., Snyder-Mackler, L., Reich, T. \& Lindstedt, S. L. (2003). Eccentric Muscle Contractions: Their Contribution to Injury, Prevention, Rehabilitation, and Sport. Journal of Orthopaedic \& Sports Physical Therapy, 33(10), 557-571. https://doi.org/10.2519/jospt.2003.33.10.557

13. Li, H.-Y. \& Hua, Y. (2016). Achilles Tendinopathy: Current Concepts about the Basic Science and Clinical Treatments. BioMed Research International, 2016, 1-9. https://doi.org/10.1155/2016/6492597

14. Lieberman, D. (2016). Př́běh lidského těla: evoluce, zdraví a nemoci. (J. Vicari, Přel.).

15. Lieberman, D. E., Venkadesan, M., Werbel, W. A., Daoud, A. I., D’Andrea, S., Davis, I. S., ... Pitsiladis, Y. (2010). Foot strike patterns and collision forces in habitually barefoot versus shod runners. Nature, 463(7280), 531-535. https://doi. org/10.1038/nature08723

16. Madden, C., Putukian, M., McCarty, E. \& Young, C. (2013). Netter's Sports Medicine. Elsevier Health Sciences.

17. Maffulli, N., Sharma, P. \& Luscombe, K. L. (2004). Achilles Tendinopathy: Aetiology and Management, Achilles Tendinopathy: Aetiology and Management. Journal of the Royal Society of Medicine, 97(10), 472-476. https://doi. org/10.1177/0141076809701004 
18. Myers, T. W. (2013). Anatomy Trains: Myofascial Meridians for Manual and Movement Therapists. Elsevier Health Sciences.

19. Ott, O. J., Jeremias, C., Gaipl, U. S., Frey, B., Schmidt, M. \& Fietkau, R. (2015). Radiotherapy for benign achillodynia. Strahlentherapie Und Onkologie, 191(12), 979-984. https://doi.org/10.1007/s00066-015-0893-4

20. Poppel, D. van, Scholten-Peeters, G. G. M., Middelkoop, M. van \& Verhagen, A. P. (2013). Prevalence, incidence and course of lower extremity injuries in runners during a 12-month follow-up period. Scandinavian Journal of Medicine \& Science in Sports, 24(6), 943-949. https://doi.org/10.1111/sms.12110

21. Ridge, S., Johnson, A., Mitchell, U., Hunter, I., Robinson, E., Rich, B. \& Brown, S. (2013). Foot Bone Marrow Edema after a 10-wk Transition to Minimalist Running Shoes. All Faculty Publications. Získáno z https://scholarsarchive.byu.edu/ facpub/2014

22. Ristolainen, L., Heinonen, A., Turunen, H., Mannström, H., Waller, B., Kettunen, J. A. \& Kujala, U. M. (2009). Type of sport is related to injury profile: A study on cross country skiers, swimmers, long-distance runners and soccer players. A retrospective 12-month study. Scandinavian Journal of Medicine \& Science in Sports, 20(3), 384-393. https://doi. org/10.1111/j.1600-0838.2009.00955.x

23. Robinson, J. M., Cook, J. L., Purdam, C., Visentini, P. J., Ross, J., Maffulli, N., ... Khan, K. M. (2001). The VISA-A questionnaire: a valid and reliable index of the clinical severity of Achilles tendinopathy. British Journal of Sports Medicine, 35(5), 335-341. https://doi.org/10.1136/bjsm.35.5.335

24. Ryan, M., Elashi, M., Newsham-West, R. \& Taunton, J. (2013). Examining injury risk and pain perception in runners using minimalist footwear. Br J Sports Med, bjsports-2012-092061. https://doi.org/10.1136/bjsports-2012-092061

25. Simons, D. G. \& Travell, J. G. (1999). Travell \& Simons' Myofascial Pain and Dysfunction: The lower extremities. Williams \&Wilkins.

26. Sobhani, S., Dekker, R., Postema, K. \& Dijkstra, P. U. (2012). Epidemiology of ankle and foot overuse injuries in sports: A systematic review. Scandinavian Journal of Medicine \& Science in Sports, 23(6), 669-686. https://doi.org/10.1111/j.16000838.2012.01509.x

27. Stasinopoulos, D. \& Manias, P. (2013). Comparing two eccentric exercise programmes for the management of Achilles tendinopathy. A pilot trial. Journal of Bodywork and Movement Therapies, 17(3), 309-315. https://doi.org/10.1016/ j.jbmt.2012.11.003

28. Theisen, D., Malisoux, L., Gette, P., Nührenbörger, C. \& Urhausen, A. (2016). Footwear and running-related injuries Running on faith? Sports Orthopaedics and Traumatology, 32(2), 169-176. https://doi.org/10.1016/j.orthtr.2016.03.047

29. Tvrzník, A. \& Gerich, D. (2014). Velká kniha běhání. Grada Publishing a.s. 